\title{
Temporal and spatial variation in the distribution of epineustonic competent larvae of Concholepas concholepas along the central coast of Chile
}

\author{
Elie Poulin, Alvaro T. Palma*, Germán Leiva, Eduardo Hernández, Pilar Martínez, \\ Sergio A. Navarrete**, Juan C. Castilla
}

Departamento de Ecología, Estación Costera de Investigaciones Marinas Las Cruces and Center for Advanced Studies in Ecology and Biodiversity, Pontificia Universidad Católica de Chile, Alameda 340, Casilla 114-D, Santiago CP 6513677, Chile

\begin{abstract}
The abundance of competent epineustonic larvae of the gastropod Concholepas concholepas (Gastropoda: Muricidae) in nearshore waters at 2 sites along the central coast of Chile was examined through monthly plankton tows from July 1999 to June 2000. Larvae were found in plankton collections from July 1999 to February 2000 with maximum abundance in September and October. Settlement in artificial collectors deployed onshore on the lower intertidal zone showed the same unimodal pattern with a settlement peak during October and November. Variation in larval distribution among sampling dates was related to the occurrence of north-south winds. We found that C. concholepas larvae were more abundant closer to shore after moderate southerly wind periods than on calm days, probably because of the shoreward advection of the upper sea surface layer. While sampling during a strong coastal upwelling event (produced by strong southwesterly winds), C. concholepas larvae were only found in the upwelled waters between the front and the coast. This unusual pattern contrasts with what would be expected for typical epineustonic larvae, suggesting the existence of a mechanism of transport or retention by which $C$. concholepas larvae stay near coastal settling areas, thus avoiding offshore dispersion.
\end{abstract}

KEY WORDS: Concholepas concholepas · Larval distribution · Settlement · Upwelling · Wind speed

\section{INTRODUCTION}

For many coastal benthic invertebrates, dispersive planktonic larvae represent a critical phase in their life cycle (Thorson 1950). Settlement, defined here as the transition between the planktonic larval phase and life in the benthos, is followed by recruitment, i.e. the incorporation of new individuals into benthic populations. Settlement is determined by the interaction of larval characteristics (i.e. developmental mode, larval duration) with oceanographic and geographic factors (i.e. coastal circulation and coast-line configuration) (Archambault \& Bourget 1999). In contrast to terrestrial plants, for which

\footnotetext{
* Present address: Departamento de Ecología Costera, Facultad de Ciencias, Universidad Católica de la Santísima Concepción Paicavi 3000, Casilla 297, Concepción CP 4073978, Chile

${ }^{* *}$ Corresponding author. E-mail: snavarre@bio.puc.cl
}

seed dispersal patterns are generally inversely proportional to the distance from the parental sources (Nathan \& Muller-Landau 2000), it is thought that marine benthic invertebrate larvae are transported extensively by ocean circulation away from the parental population, thereby decoupling local reproduction from recruitment (Strathmann 1990, Caley et al. 1996). When released, planktonic larvae of intertidal and subtidal species are first driven by coastal currents and then possibly transported by the general oceanic circulation, sometimes over long distances (Mileikovsky 1968, Scheltema 1971, 1986). During this period, ranging from a few days to several months, losses due to predation or competition for food are common (Sale 1990). The onshore migration of competent larvae back to the adult habitat is a critical period because regional or local oceanographic events, as well as coastline configuration, may determine the number of settlers and therefore the success of the benthic population (Archambault \& Bourget 1999, Incze 
et al. 2000, Shanks et al. 2000). Coastal oceanic frontal features, generated, for example, by internal waves or upwelling dynamics, can play an important role in the horizontal advection of larvae into coastal sites (Kingsford 1990, Pineda 1991, 1999, Shanks 1995, Shanks et al. 2000). At the local scale, small physical and biotic environmental heterogeneity will determine settlement patterns (Eckman 1983, Bourget et al. 1994, Miron et al. 1996, Guichard \& Bourget 1998, Incze et al. 2000, Jeffery \& Underwood 2000, Navarrete \& Wieters 2000). These characteristics, in which local populations receive propagules from distant sites, has led to the assumption that populations of benthic marine species with planktonic larval phase are open (Gaines \& Roughgarden 1985, Roughgarden et al. 1985, 1988, Possingham \& Roughgarden 1990, Caley et al. 1996). An important consequence of such an open population structure is that settlement rates are highly variable and usually unpredictable in space and time. Therefore, quantifying patterns of spatial and temporal variation in settlement as well as identifying the processes responsible for such variation has become a central issue in marine ecology.

Because of its high economic value and the important ecological role it plays in intertidal and subtidal communities, the muricid gastropod Concholepas concholepas (Bruguière 1789), locally known as 'loco', has been intensively studied in the past 2 decades along the coast of Chile (Castilla \& Durán 1985, Moreno et al. 1986, Durán \& Castilla 1989, Power et al. 1996, Castilla 1999, 2000). Consumed by humans since prehispanic times (Jerardino et al. 1992), this species has suffered from increasing exploitation since the mid-1970s. At the beginning of the 1980s, it became the largest gastropod fishery in the world (FAO 1982, Castilla \& Jerez 1986). However, at the same time, signs of it being strongly overexploited were detected (Castilla 1995, Castilla \& Fernández 1998).

The known geographic distribution of Concholepas concholepas extends from central Peru to Cape Horn including the Juan Fernández Archipelago (Beu 1970, Stuardo 1979). Adult individuals live on rocky bottoms in the intertidal and subtidal zones down to approximately $30 \mathrm{~m}$ in depth. This species is one of the top predators in these systems, consuming a variety of sessile filter feeders such as barnacles, mussels and tunicates (Castilla et al. 1979, Guisado \& Castilla 1983, Moreno et al. 1986). In central Chile, C. concholepas females lay egg capsules on low intertidal and shallow subtidal rocky surfaces during the fall months (Manríquez \& Castilla 2001). After approximately 1 mo of intracapsular development, small veliger larvae (ca. $260 \mu \mathrm{m}$ ) are released and spend the next 3 mo in the water column (Gallardo 1979, DiSalvo 1988). There is evidence suggesting that $C$. concholepas veligers stay near the bottom during at least the first week of development, thereby probably decreasing dispersion (Moreno et al. 1993). Once the larvae become competent, they dwell at the sea surface feeding on plankton until they metamorphose on rocky intertidal and shallow subtidal bottoms. Settlement of the epineustonic competent lipped veligers has been well documented in the low intertidal zone, where newly settled individuals are generally found associated with small barnacles and mussels (Castilla et al. 1979, Gallardo 1979, Guisado \& Castilla 1983, Rivas \& Castilla 1987, Stotz et al. 1991). Although settlement has not been quantified in the subtidal zone, newly settled $C$. concholepas have been found at depths of up to $30 \mathrm{~m}$ (Arias 1991, Stotz et al. 1991, Moreno et al. 1993).

Although the developmental sequence of Concholepas concholepas larvae is well known, little has been done to understand their spatial distribution, especially in water masses near the coast. During the past decade, 2 studies have investigated the relationships between local wind forcing, large-scale oceanographic phenomena such as El Niño Southern Oscillation (ENSO), and C. concholepas settlement (Moreno et al. 1993, 1998). Evidence from these studies suggests that settlement of $C$. concholepas could be related to the dynamics of local surface winds over the ocean. The authors hypothesize that alternate sequences of southerly and northerly winds that generate successive upwelling and relaxation events, respectively, may be the principal mechanism by which competent larvae of C. concholepas are advected towards the shore. This onshore transport mechanism may be disrupted by events such as El Niño and La Niña, apparently explaining the species recruitment failure observed during El Niño phenomena (Moreno et al. 1998).

In this study, we primarily attempt to investigate the physical aspects that are most likely to affect the spatial distribution of competent larvae of Concholepas concholepas in waters adjacent to the shore $(<5 \mathrm{~km})$, and which might be related to the subsequent patterns of local recruitment. Specifically our objectives were to investigate in nearshore environments: (1) the annual variation in the abundance of larvae and newly settled individuals; (2) the spatial variation of larval abundance among sampling dates (monthly) in relation to hydrographic factors, such as wind stress and water column temperature; and (3) the pattern of distribution and abundance of larvae during a strong upwelling event.

\section{MATERIALS AND METHODS}

Study sites and sampling design. From July 1999 through June 2000, surface zooplankton samples were 
collected monthly during daylight hours in front of 2 localities along the central coast of Chile: El Quisco (S 33 $23^{\prime} 48.9^{\prime \prime}, \mathrm{W} 71^{\circ} 41^{\prime} 40.5^{\prime \prime}$ ) and Las Cruces (S $33^{\circ}$ $30^{\prime} 06.3^{\prime \prime}, \mathrm{W} 71^{\circ} 38^{\prime} 02.0^{\prime \prime}$ ), which are ca. $15 \mathrm{~km}$ apart (Fig. 1). Samples were collected using a floating neuston net with a $700 \mu \mathrm{m}$ mesh size, (as described by DiSalvo 1988), which has been especially designed to collect premetamorphic larvae of Concholepas concholepas in the top few centimeters of the water column. The field sampling scheme utilized throughout this study consisted of six and five $1.8 \mathrm{~km}$ long transects parallel to the coast off El Quisco and Las Cruces, respectively (hereafter referred as EQ and LC). The distance of the transects from the shore ranged from 50 to $4000 \mathrm{~m}$ (see details in Fig. 1). Because the rectangular mouth of this neustonic net is not totally submerged, and because competent $C$. concholepas lar-

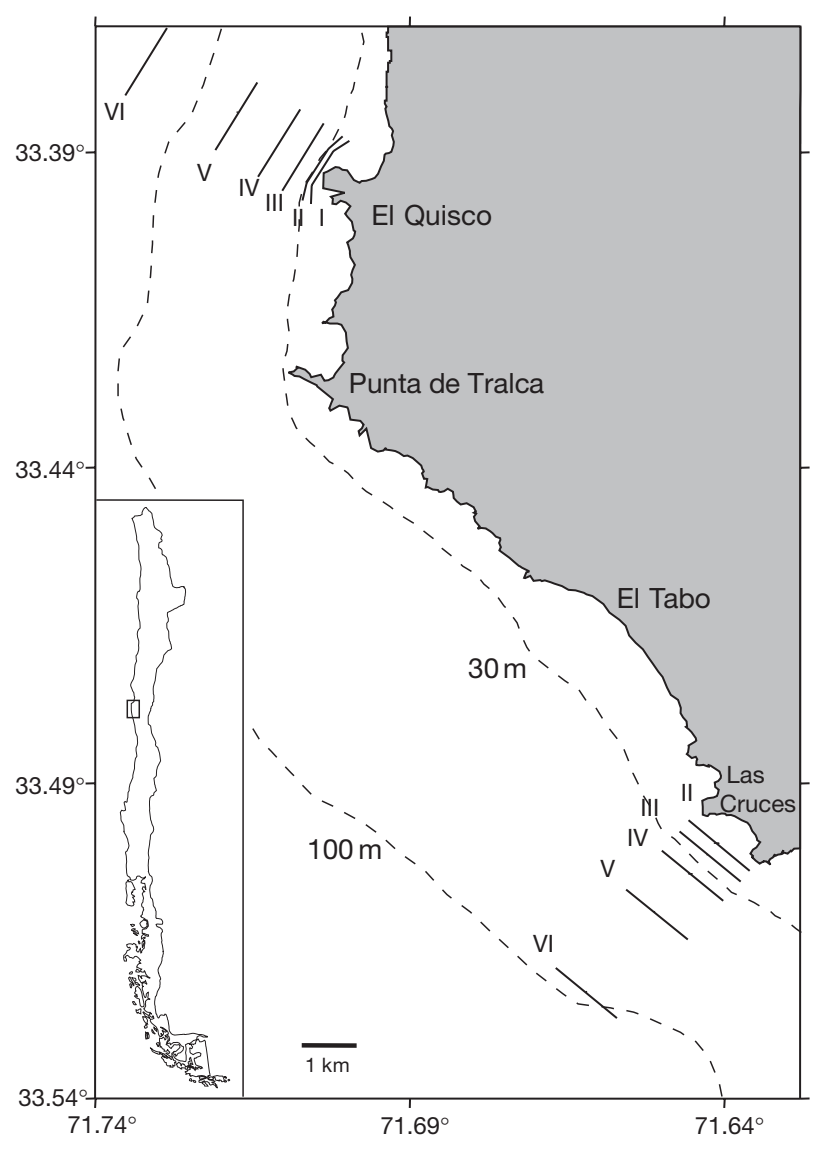

Fig. 1. Map showing the study sites (El Quisco and Las Cruces) and the grid sampling design. Transects are 1 nautical mile in length. In El Quisco the distance of transects from the shore is: $50 \mathrm{~m}$ for I, $150 \mathrm{~m}$ for II, 500 for III, $1000 \mathrm{~m}$ for IV, $2000 \mathrm{~m}$ for $\mathrm{V}$, and $4000 \mathrm{~m}$ for VI. In Las Cruces, the distance of transects from the shore is: $100 \mathrm{~m}$ for II, $500 \mathrm{~m}$ for III, $1000 \mathrm{~m}$ for IV, $2000 \mathrm{~m}$ for $\mathrm{V}$, and $4000 \mathrm{~m}$ for VI. Broken lines represent the 30 and $100 \mathrm{~m}$ isobaths. See 'Materials and methods' for details vae are suspended in the first centimeters of the water column, larval abundance were simply expressed as number of larvae per $\mathrm{km}$ towed. For each transect, towed distance was directly measured from a flow meter attached to the net. Plankton samples were preserved in a $5 \%$ buffered formaldehyde seawater solution. Larvae were then identified and counted in the laboratory under a dissecting microscope. At the beginning and end of each transect, surface to $25 \mathrm{~m}$ deep profiles of several water column variables were measured (temperature, dissolved oxygen, salinity) using a CTD profiler (Seabird-19).

To determine potential differences in larval distribution and abundance between day and night, 2 additional cruises were conducted during a night in September and another in October of 1999 (period of maximum larval abundance) at EQ. These collections were made the night before the regular day surveys of September and October off EQ at 3 transects (II, IV and $\mathrm{V}$ in Fig. 1). To characterize larval distribution during strong equatorward winds, an additional sampling during day hours was conducted on November 5, 1999, off $E Q$, on a day of strong southerly, upwelling favorable winds. Strong equatorward winds are here defined as those that persist for a minimum of 3 to $4 \mathrm{~d}$ with a constant speed of about 30 to $40 \mathrm{~km} \mathrm{~h}^{-1}$ during the day, separated by lower wind speed at night. To ensure that the area surveyed extended beyond the coastal upwelled waters, the sampling scheme was modified and consisted of seven $1 \mathrm{~km}$ long transects parallel to the coastline at distances of $1,2,4,6,8,10$, and $12 \mathrm{~km}$ from the shore.

Quantification of settlement rates of Concholepas concholepas were made by deploying artificial collectors $(n=20)$ in the low intertidal zone of LC. The collectors were plastic scrubbing pads $\left(\right.$ Tuffy $^{\circledR}$ ) approximately $10 \mathrm{~cm}$ in diameter, which were fixed to the rock surface using stainless steel screws (see Menge et al. 1994). Between July 1999 and June 2000, collectors were surveyed approximately every $15 \mathrm{~d}$, when they were replaced with new ones and brought to the lab for analysis under a dissecting microscope.

Larval spatial distribution. To compare larval spatial distribution among the regular cruises, we calculated the center of gravity $G$ for each sampling date in LC based on larval abundance in each transect and the distance of transects to the shore:

$$
G=\sum\left(N_{t}^{*} D_{t}\right) / \Sigma N_{t}
$$

where $N_{t}$ is the number of larvae per km in transect $t_{\text {, }}$ and $D_{t}$ the distance of transect $t$ to the coast. Thus, $G$ represents the average distance to the shore of all larvae during a given cruise and is expressed in $\mathrm{m}$. 
Only data for LC could be used in this analysis because spatial gaps in the data at EQ did not permit a meaningful calculation of $G$.

Hydrography and larval distribution. Wind speed and direction were recorded as vector averages every 10 min by a meteorological station located at the Coastal Marine Research Station at Las Cruces (ECIM). Sea surface temperature was measured with temperature loggers (Stow Away ${ }^{\circledR}$ Tidbits) located subtidally approximately $1 \mathrm{~m}$ below the extreme lowwater neap (Lewis 1964) in front of the 2 study sites. These loggers recorded temperature at $30 \mathrm{~min}$ intervals.

The potential relationship between wind speed and larval spatial distribution (G-values) was investigated through ordinary least-squares regression analyses. Since the effect of wind on the upper sea surface, and therefore on the distribution of epineustonic larvae, can have a time delay, our analyses considered the daily values of wind speed components (northsouth, east-west) registered at time lags between 0 and up to $4 \mathrm{~d}$ prior to larval sampling. Several regressions were performed that accounted for the average wind speed values obtained during the same larval sampling date, and then the data for the previous $4 \mathrm{~d}$ were successively pooled. The same procedure was performed for the daily wind speed maxima, which were successively averaged at different time lags prior to the larval sampling dates. Each wind speed value was associated with the corresponding larval distribution $G$-value in order to find the best fit.

The relationship between wind speed and sea surface temperature (SST) during the period when competent Concholepas concholepas larvae were present in the water (July 1999 to February 2000) was studied through a cross-correlation analysis (Box \& Jenkins 1976). This analysis was done using the daily mean temperature, and the daily mean and maximum wind speed components. Since temperature increased steadily during this period, due to summer heating, values were detrended. To determine whether daily changes in SST were coupled between sites, we looked at the degree of correlation of mean daily SST between LC and EQ. Ekman transport $\left(M_{\mathrm{x}}\right)$ was estimated $\left(\mathrm{m}^{3} \mathrm{~s}^{-1} \mathrm{~km}^{-1}\right)$ following equations in Mann \& Lazier (1996, p. 145):

$$
M_{\mathrm{X}}=-\tau / f
$$

where $\tau$ is the north-south wind stress component at the surface and $f$ is the Coriolis parameter at the studied latitude. The $M_{x}$ daily mean values were related to daily mean sea surface temperature to detect whether high $M_{x}$ values were associated with a subsequent decrease in sea surface temperature.

\section{RESULTS}

\section{Patterns of larval distribution and post-settlement abundance}

Competent Concholepas concholepas larvae were found in surface waters between August (beginning of austral spring) and March (end of austral summer). Monthly larval abundance followed a unimodal pattern, with a maximum in September and October at EQ and LC (Fig. 2a,b).

No competent Concholepas concholepas larvae were found in the 2 nocturnal sampling cruises
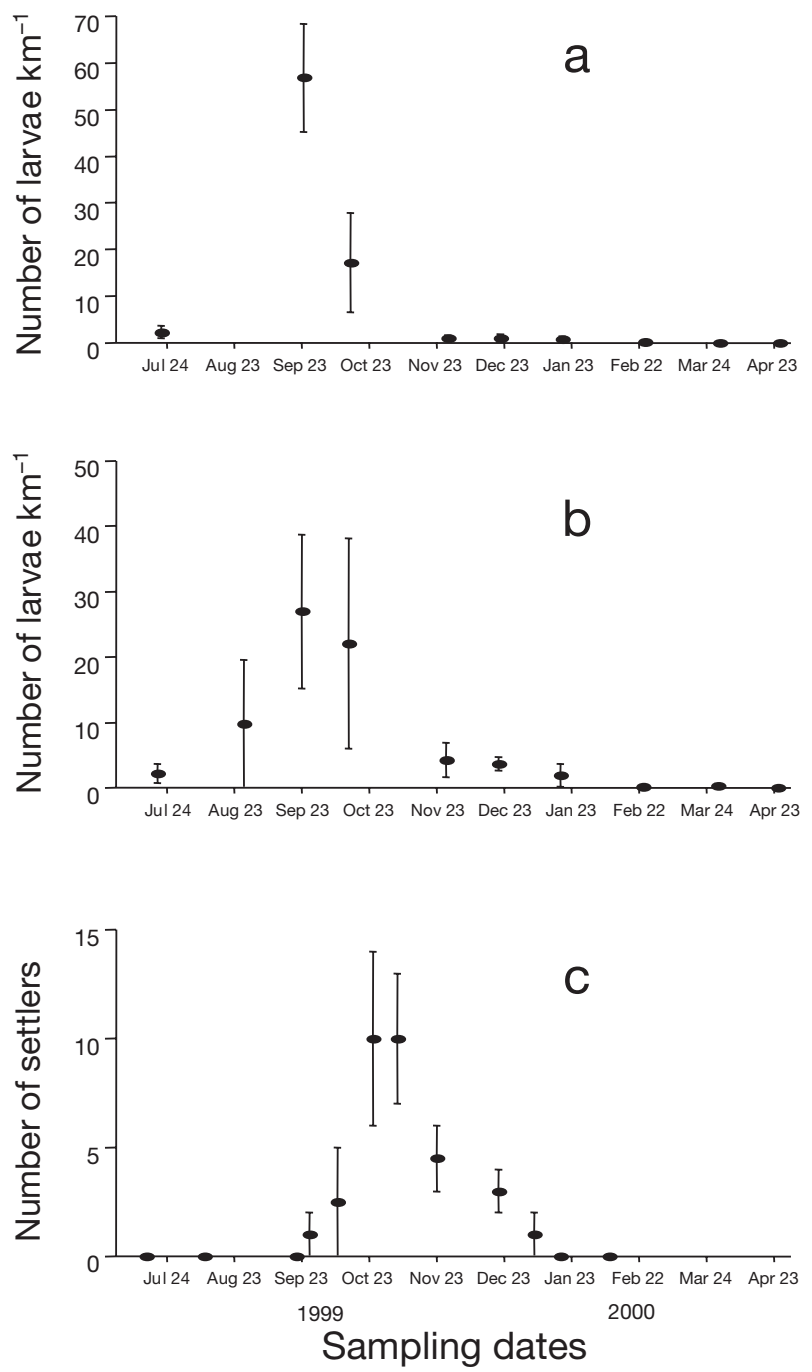

Fig. 2. Concholepas concholepas larvae. Monthly abundance at the 2 sampling sites, (a) El Quisco and (b) Las Cruces. Values represent the average among all transects for each cruise/sampling date. (c) Values represent the average number of newly settled individuals found in artificial collectors at Las Cruces 
conducted in September and October, while relatively high larval concentrations were observed at the same 3 transects the following day $(127,175$, and 45 in transects EQII, IV, and V respectively in September, and 54, and 11 in EQII, and IV respectively in October). No changes in the properties of water masses (CTD data) were detected between the above day/night surveys.

The temporal pattern of settlement of Concholepas concholepas in artificial collectors followed the same general unimodal pattern observed in larval abundance off LC and EQ (Fig. 2c). The maximum number of newly settled individuals occurred from September to December, a few weeks after the maximum larval abundance was observed in coastal waters (Fig. 2a,b).

At LC, the spatial distribution of larvae in transects at different distances from the shore varied considerably over time (Fig. 3). For this analysis, we only considered the 7 mo of sampling in LC, when larvae were most abundant ( $>1$ larva $\mathrm{km}^{-1}$ ). In some cases like in October 1999 and in January 2000, larvae were mainly or totally found in transects closest to shore. In August and November, however, nearly all larvae were collected further offshore (Fig. 3).

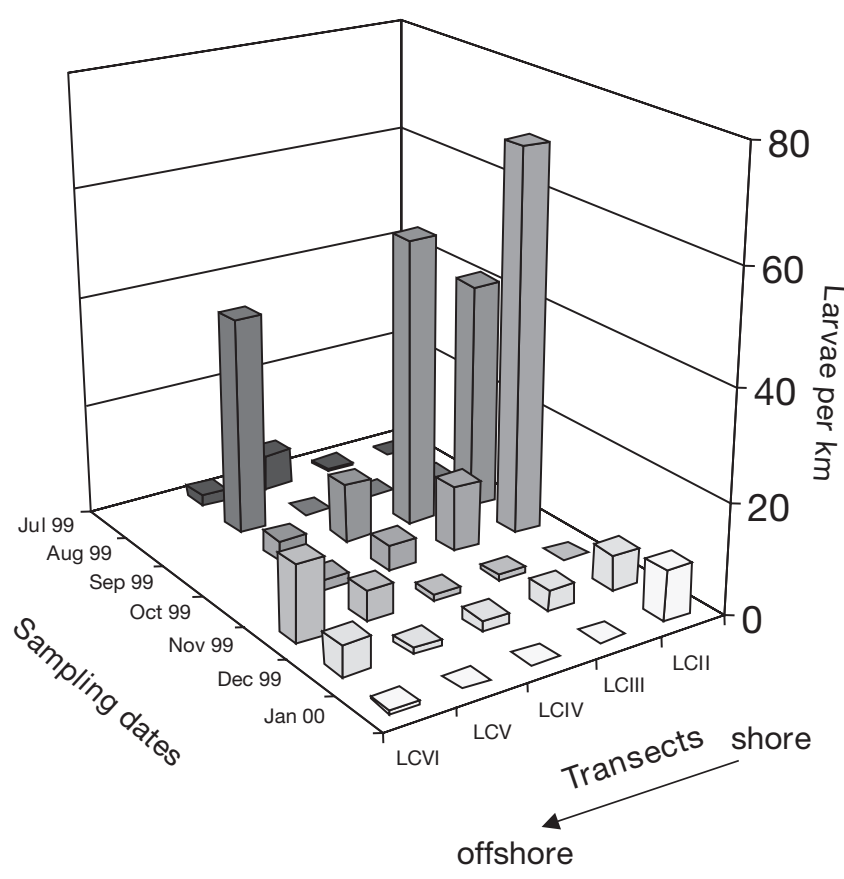

Fig. 3. Concholepas concholepas larvae. No. $\mathrm{km}^{-1}$ at the different transects and for the different sampling dates. Only the 7 mo when larvae where most abundant $\left(>1\right.$ larva $\left.\mathrm{km}^{-1}\right)$ were considered

\section{Relationship between wind speed and larval distribution}

Regression analyses detected no statistically significant relationship between the east-west component of the winds and larval spatial distribution (G-values). However, there was a positive and significant relationship between the north-south wind component and larval distribution, indicating that larvae were closer to shore on days of moderate southerly winds (daily average $<10 \mathrm{~km} \mathrm{~h}^{-1}$ ) than on calm days. The relationship was stronger when the maximum daily values of the north-south wind component included the 1 and $2 \mathrm{~d}$ delay before the larval sampling $\left(1 \mathrm{~d}: \mathrm{r}^{2}=0.80, \mathrm{p}=\right.$ $0.01 ; 2 \mathrm{~d}: \mathrm{r}^{2}=0.72, \mathrm{p}=0.02$ ). This relationship was also significant using daily mean values of the north-south wind component with a $2 \mathrm{~d}$ delay $\left(\mathrm{r}^{2}=0.61, \mathrm{p}=0.04\right.$; Fig. 4). In all cases, there was a positive correlation between north-south wind and larval distribution when the mean and the maximum wind speed values were calculated using a 2 to $5 \mathrm{~d}$ delay prior the surveys. This was not the case when only maximum or mean wind data for the same day of larval collection were considered $\left(\mathrm{r}^{2}=0.1, \mathrm{p}=0.49 ; \mathrm{r}^{2}=0.03, \mathrm{p}=0.71\right.$, respectively).

No correlation was found between the east-west wind speed component and the detrended sea surface temperature. However, the same analyses using the north-south wind speed component showed significant positive correlation for each time lag between 1 and $9 \mathrm{~d}(\mathrm{p}<0.05)$ for daily mean and maximum values,

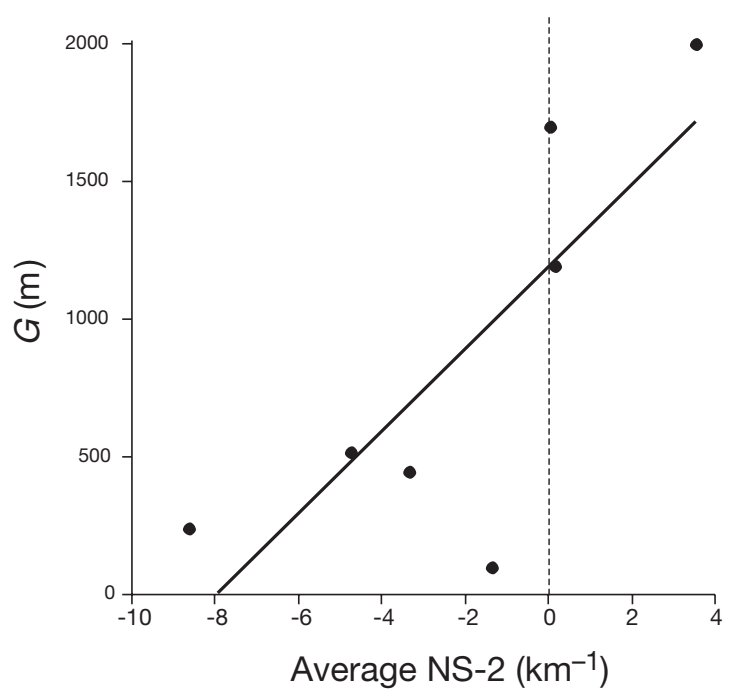

Fig. 4. Linear regression analysis between the average daily values of the north-south wind speed component (NS-2: mean daily average wind speed of previous $3 \mathrm{~d}$ ) and the center of gravity $(G)$ of larval spatial distribution. Positive values in the horizontal axis correspond to northerly winds and negative ones to southerly winds 


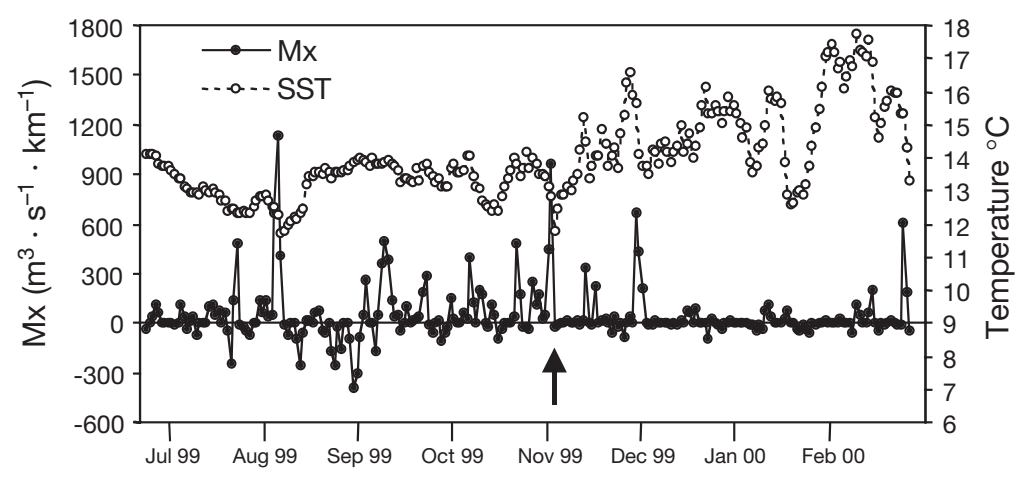

Fig. 5. Values of daily mean Ekman transport index $\left(M_{x} \bullet \bullet\right)$ plotted against daily mean values of sea surface temperature (O). Arrow indicates the day when the November 5 cruise took place

indicating that north-south winds were correlated with SST drops. The cross-correlation coefficient $r$ was computed following the standard formulas, as described in most time series references (e.g. Box \& Jenkins 1976).

\section{Larval distribution during coastal upwelling conditions}

The daily mean variation in Ekman transport during the 7 mo of high larval abundance (July to January) showed that the highest values of Ekman transport were soon followed by conspicuous drops in sea surface temperature (Fig. 5), suggesting that coastal upwelling was occurring in the study area. However, significant drops in temperature between December and February were not necessarily associated to intensification of upwelling favorable winds (Fig. 5). The crosscorrelation analysis of sea surface temperature between the 2 study sites (EQ and LC) was highly significant at a time lag of 0 days ( $\mathrm{r}=0.756, \mathrm{p}<0.001)$.

The additional survey of November 5, which was conducted to assess larval distribution during strong local upwelling conditions (Fig. 6a), corresponded to the second major daily mean Ekman value during the time period considered $\left(M_{X}=964\right.$, see arrow in Fig. 5). In the thermal section obtained during this cruise, the water column showed a cold-water wedge $\left(10\right.$ to $12.5^{\circ} \mathrm{C}$ ) that reached the surface between the shore and 6 to $8 \mathrm{~km}$ offshore (Fig. 6a), the same area where all larvae were found during this cruise. The same pattern was also observed for dissolved oxygen concentration, with the values at the sea surface for the first $8 \mathrm{~km}$ ranging between 5.0 and $6.5 \mathrm{mgl}^{-1}$. In a similar fashion, salinity values were higher in the coastal zone ranging from 34.2 to $34.35 \%$ o. In contrast, during the regular November 28 cruise in EQ, the water column showed the typical vertical stratification following a period of moderate wind regime (non-upwelling condition, Fig. 6b).
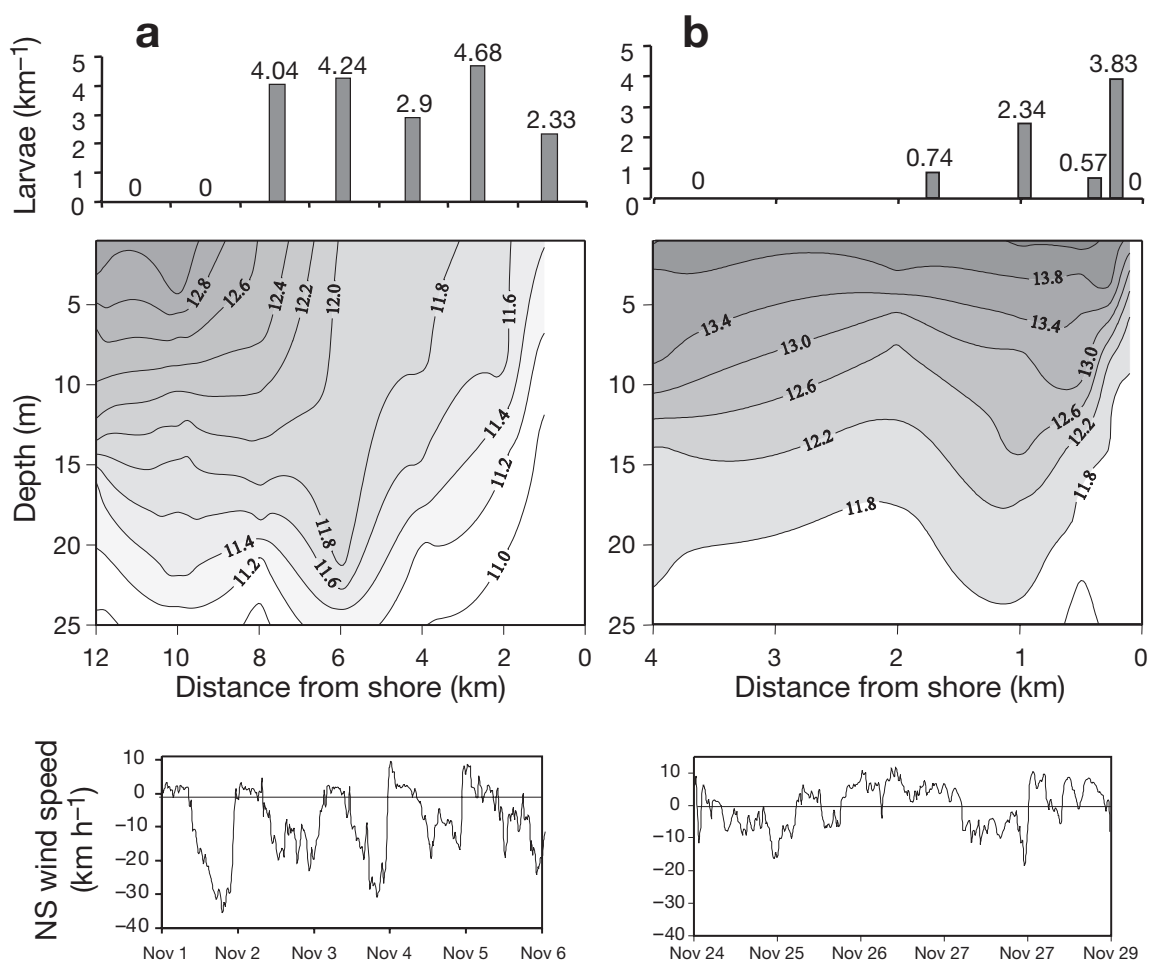

Fig. 6. (a) Cross-shelf transects of vertical temperature profiles showing the distribution of isotherms during an upwelling event (middle panel), the corresponding spatial occurrence of competent larvae found at the sea surface (top panel), and the north-south wind speed components during the same sampling date and $4 \mathrm{~d}$ before (bottom panel); (b) shows the same type of information but during the November regular cruise under upwelling relaxation conditions. Distance scales differ between (a) and (b) because they correspond to different sampling grids 


\section{DISCUSSION}

This study confirms that epineustonic competent Concholepas concholepas larvae are rare components of the coastal surface plankton of Chile (Knickmeier \& Stotz 1991, Moreno et al. 1993, DiSalvo \& Carriker 1994, Peña et al. 1994). Maximum larval abundance occurs during the spring months off Las Cruces and El Quisco, as observed in other studies in north-central Chile (Knickmeier \& Stotz 1991, DiSalvo \& Carriker 1994). This evidence also confirms that the reproductive cycle of $C$. concholepas follows a seasonal pattern (Ramorino 1975, Castilla 1979). In our study, C. concholepas larval abundance and settlement also follows a seasonal pattern. Although the timing of maximum larval occurrence and subsequent settlement may differ in other regions of Chile, it still shows a seasonal pattern, and seems to follow a latitudinal gradient (Lépez \& Moreno 1988, Moreno et al. 1993, 1998, Peña et al. 1994).

In addition to the monthly variations in larval abundance, this study shows evidence of larval spatial variability among sampling dates in the nearshore area considered (Fig. 3). Because recruitment of Concholepas concholepas occurs only in the intertidal and shallow subtidal zone (down to $30 \mathrm{~m}$ deep, Arias 1991, Stotz et al. 1991), and given the steep shelf characteristic of these sites, successful settlement probably occurs only within a few hundred meters from shore (Transects II and III on our sampling grid in LC, and I and II in EQ, see Fig. 1). Thus, when larvae were mostly or totally found in the transects further offshore, no settlement would be expected to occur. Settlement pulses probably only happen when $C$. concholepas larvae are located within approximately $500 \mathrm{~m}$ from the shore. Unfortunately, because of the naturally low density of C. concholepas larvae in the plankton, it was not possible to verify this hypothesis through a daily monitoring of settlement in artificial collectors. Indeed, the maximum settlement rate in artificial collectors did not exceed 2 to 3 settlers per collector per $15 \mathrm{~d}$. This low settlement rate, as well as the delay observed between larval abundance and settlement peacks, could be a consequence of the broad sampling time interval.

\section{Effect of moderate southerly winds on larval distribution}

There was a positive relationship between the northsouth wind speed component and the spatial distribution of larvae off LC (Fig. 4). Indeed, the southerly component of the wind speed correlates with the presence of larvae near the shore. The strongest relation- ship occurred when we considered a time lag of more than $1 \mathrm{~d}$ between wind speed and larval distribution. This agrees well with the fact that the wind forcing has a delayed effect on the dynamics of water masses (Marín et al. 1993, Wing et al. 1995a). Our results suggest that southerly winds advect competent larvae of Concholepas concholepas towards the shore. The effect that wind-driven currents have on the dispersal and transport of larvae depends on the depth at which these larvae reside. Since competent $C$. concholepas larvae thrive at the surface, they are subject to be transported nearly downwind and at around $3 \%$ of the wind speed (Shanks 1995). Thus, after moderate southerly winds, larvae were probably entrained in waters near the shore of LC, which is oriented in a north-west to south-east direction (see Fig. 1).

\section{Nearshore larval retention during coastal upwelling conditions}

In our study area and during most of the period when competent Concholepas concholepas larvae were present, the water column was stratified with a fairly constant thermocline found between 10 and $15 \mathrm{~m}$ below MLW (Fig. 6b). However, during the study period we found evidence for the occurrence of several coastal upwelling events. These events result from the offshore movement of the upper sea surface layer of the water column (above the well-established thermocline), lifting colder and relatively shallow water masses towards the shore. Moreover, the depth range for onshore movement in the Peru-Chile upwelling system is particularly shallow, probably as a result of the extreme narrowness of the shelf (Tomczak \& Godfrey 1994, p. 144). Our direct evidence for the occurrence of shallow coastal upwelling events is based on different and independent measurements: (1) the significant relationship between equatorward winds and the drop in sea surface temperature at $\mathrm{LC}_{i}$ (2) high values of Ekman transport $\left(M_{x}>500 \mathrm{~m}^{3} \mathrm{~s}^{-1}\right.$ $\mathrm{km}^{-1}$ ) were associated with abrupt drops in sea surface temperature (Fig. 5); (3) the similar temporal pattern in sea surface temperature variation between EQ and LC, demonstrates that the phenomenon occurs simultaneously over 10s of kilometers; and (4) the shape of the thermal section on the transects sampled on November 5 (period of strong upwelling index) indicates that upwelling was occurring close to shore. As represented in Fig. 6a, the temperature section shows a clear pattern of cold water being upwelled near the coast with the thermocline breaking the surface between 6 and $8 \mathrm{~km}$ from the shore.

A hypothesis based on local upwelling has been frequently proposed to explain offshore and inshore 
advection of larvae that live at or near the surface (Roughgarden et al. 1991, Wing et al. 1995a,b, Miller \& Emlet 1997). It assumes that during upwelling events, larvae in the neuston are transported offshore as a consequence of the horizontal displacement of the surficial waters. During periods of relaxation, the upwelling front would transport larvae back toward the shore, thus favoring their settlement. Occurrence of such a phenomena has been elegantly demonstrated by Shanks et al. (2000) along the coast of North Carolina. The authors showed that different types of invertebrate larvae, including gastropods, were transported shoreward by the front during the relaxation phase of the upwelling event. Based on this model, we would then expect to find competent Concholepas concholepas larvae distributed offshore and concentrated at the front during strong upwelling favorable southerly wind conditions. On the contrary, in our study area, characterized by intermittent upwelling events (Strub et al. 1998), competent $C$. concholepas larvae were exclusively found between the upwelling front and the shore (Fig. 6a). Since offshore transport is expected to be strong during upwelling conditions, C. concholepas larvae must find a way to remain in nearshore upwelled waters. The absence of larvae at the sea surface during our night surveys suggests that this species could be potentially capable of reverse vertical migration (migration down into the water column at night). If so, at night, larvae would reach the cold deeper layer below the thermocline (ca. $15 \mathrm{~m}$ depth) and would then be transported shoreward by the upwelled waters. For example, there is evidence showing that reverse vertical migration can play a role in the net shore advection of crab larvae, taking advantage of inshore-offshore sea breezes (Shanks 1986). Although there are some laboratory observations on behavioral and physical characteristics of competent $C$. concholepas larvae that would support their vertical migration capabilities, they are not conclusive. The presence of a byssal thread (DiSalvo 1988, DiSalvo \& Carriker 1994) and the observations of a bubble capture mechanism (P. H. Manríquez pers. obs.) by these larvae support our suggestion of vertical migration.

\section{CONCLUSIONS}

This study demonstrates how southerly winds, dominant for this region during spring and summer time (Reyes \& Romero 1977, Sievers \& Silva 1979, Avaria et al. 1989, Rosales \& Balbontín 1994), can affect the spatial distribution of competent larvae of Concholepas concholepas. On the one hand, moderate southerly winds may favor the direct advection of larvae towards the coast (surficial downwind transport,
Shanks 1995). On the other hand, when southerly winds are strong enough to provoke upwelling, the reverse vertical migration of competent $C$. concholepas larvae could allow their retention between the upwelling front and the shore. Further evidence supporting the existence of this potential retention mechanism should guide future research efforts, particularly those concerning the role of vertical migration affecting larval transport, toward settlement habitats.

Acknowledgements. We would like to thank the enthusiastic field assistance of R. Pacheco, F. Veliz, A. Rosson, D. Narvaez and M. Andrade, skipper of the 'Barracuda', for his disposition and expertise. This manuscript was greatly improved by the helpful comments of A. Shanks. This research was also supported by: Proyecto Italia (CICS-Eula Genova-PUCCH) and the Andrew Mellon-PUC grant to J.C.C. and S.A.N.; FONDAP O\&BM No. 3 to S.A.N. and FONDECYT No. 3990032 to A.T.P.

\section{LITERATURE CITED}

Archambault P, Bourget E (1999) Influence of shoreline configuration on spatial variation of meroplanktonic larvae, recruitment and diversity of benthic subtidal communities. J Exp Mar Biol Ecol 241:309-333

Arias E (1991) Reclutamiento de Concholepas concholepas en la zona submareal de Chiloé, Chile. Proc XI Jornadas de Ciencias del Mar, Viña del Mar, p 8

Avaria S, Palma S, Sievers H, Silva N (1989) Revision sobre aspectos oceanográficos fisicos, quimicos y planctológicos de la bahía de Valparaiso y áreas adyacentes. Biol Pesq 18:67-96

Beu AG (1970) Taxonomic position of Lippistes pehuensis Marwick, with a review of the species of Concholepas (Gastropoda, Muricidae). J Malacol Soc Aust 2:39-46

Bourget E, DeGuise J, Daigle G (1994) Scales of substratum heterogeneity, structural complexity, and the early establishment of a marine epibenthic community. J Exp Mar Biol Ecol 181:31-51

Box GEP, Jenkins GM (1976) Time series analysis: forecasting and control. Holden-Day, San Francisco

Caley MJ, Carr MH, Hixon MA, Hughes TP, Jones GP, Menge BA (1996) Recruitment and the local dynamics of open marine populations. Annu Rev Ecol Syst 27:477-500

Castilla JC (1979) Concholepas concholepas (Mollusca: Gastropoda: Muricidae): posturas de cápsulas en el laboratorio y la naturaleza. Biol Pesq 12:91-97

Castilla JC (1995) The sustainability of natural renewable resources as viewed by the fishery of the mollusc Concholepas concholepas in Chile. In: Munasinghe M, Shearer W (eds) Defining and measuring sustainability. The international bank for reconstruction and development. The World Bank, Washington, DC, p 153-159

Castilla JC (1999) Coastal marine communities: trends and perspectives from human-exclution experiments. Trends Ecol Evol 14:280-283

Castilla JC (2000) Roles of experimental marine ecology in coastal management and conservation. J Exp Mar Biol Ecol 250:3-21

Castilla JC, Durán L (1985) Human exclusion from the rocky intertidal zone of Central Chile: the effects in Concholepas concholepas (Gastropoda). Oikos 45:391-399 
Castilla JC, Fernández M (1998) Small-scale benthic fisheries in Chile: on co-management and sustainable use of benthic invertebrates. Ecol Appl 8:S124-S132

Castilla JC, Jerez J (1986) Artisanal fishery and development of a data base for managing the loco, Concholepas concholepas, resource in Chile. In: Jamieson G, Bourne N (eds) North Pacific workshop on stock assessment and management of invertebrates. Can Spec Publ Fish Aquat Sci 92, p 133-139

Castilla JC, Guisado C, Cancino J (1979) Aspectos ecologicos y conductales relacionado con la alimentacion de Concholepas concholepas (Mollusca: Gastropoda: Muricidae) Biol Pesq 12:99-114

Disalvo LH (1988) Observations on the larval and postmetamorphic life of Concholepas concholepas (Bruguière, 1789) in laboratory culture. Veliger 30:358-368

Disalvo LH, Carriker MR (1994) Planktonic, metamorphic, and early benthic behavior of the chilean loco Concholepas concholepas (Muricidae, Gastropoda. Mollusca). J Shellfish Res 13:57-66

Durán L, Castilla JC (1989) Variation and persistence of the middle rocky intertidal community of Central Chile, with and without human harvesting. Mar Biol 103:555-562

Eckman JE (1983) Hydrodynamic processes affecting benthic recruitment. Limnol Oceanogr 28:241-257

FAO (Food and Agriculture Organization of the United Nations) (1982) Yearbook of fishery statistics. Catches and landings. FAO Fish Ser 50

Gaines S, Roughgarden J (1985) Larval settlement rate: a leading determinant of structure in an ecological community of the marine intertidal zone. Proc Natl Acad Sci USA 82:3707-3711

Gallardo C (1979) El ciclo vital del Murícido Concholepas concholepas y consideraciones sobre sus primeras fases de vida en el bentos. Biol Pesq 12:79-89

Guichard F, Bourgert E (1998) Topographic heterogeneity, hydrodynamics and benthic community structure: a scale dependant cascade. Mar Ecol Prog Ser 171:59-68

Guisado C, Castilla JC (1983) Aspects of the ecology and growth of an intertidal juvenile population of Concholepas concholepas (Mollusca: Gastropoda: Muricidae) at Las Cruces, Chile. Mar Biol 78:99-103

Incze LS, Wahle RA, Palma AT (2000) Advection and settlement rates in a benthic invertebrate: recruitment to first benthic stage in Homarus americanus. ICES J Mar Sci 57:430-437

Jeffery CJ, Underwood AJ (2000) Consistent spatial patterns of arrival of larvae of the honeycomb barnacle Chamaesiphotasmanica Foster and Anderson in New South Wales. J Exp Mar Biol Ecol 252:109-127

Jerardino A, Castilla JC, Ramírez JM, Hermosilla N (1992) Early coastal subsistence patterns in Central Chile. A systematic study of the marine invertebrate fauna from the site of Curaumilla-I. Latin American Antiquity 3:43-62

Kingsford MJ (1990) Linear oceanographic features: a focus for research on recruitment processes. Aust J Ecol 15: 391-401

Knickmeier K, Stotz W (1991) Distribucion temporal y espacial de larvas de Concholepas concholepas en la IV Region, Chile. Proc XI Jornadas de Ciencias del Mar, Viña del Mar, p 42

Lépez MI, Moreno CA (1988) Recruitment of Concholepas concholepas (Bruguière, 1789) (Gastropoda, Muricidae) in the coast of Valdivia: adults and habitat type influences. Biol Pesq 17:47-56

Lewis JR (1964) The ecology of rocky shores. English Universities Press, London
Mann KH, Lazier JRN (1996) Dynamics of marine ecosystems. Blackwell Scientific Publications, Oxford

Manríquez PH, Castilla JC (2001). Significance of marine protected areas in central Chile as seeding grounds for the gastropod Concholepas concholepas. Mar Ecol Prog Ser 215:201-211

Marin V, Rodriguez L, Vallejo L, Fuenteseca J, Oyarce E (1993) Effectos de la surgencia costera sobre la productividad primaria primaveral de Bahía Mejillones del Sur (Antofagasta, Chile). Rev Chil Hist Nat 66:479-491

Menge BA, Berlow EL, Blanchette CA, Navarrete SA, Yamada SB (1994) The keystone species concept: variation in interaction strength in a rocky intertidal habitat. Ecol Monogr 64:249-286

Mileikovsky SA (1968) Some common features in the drift of pelagic larvae and juvenile stages of bottom invertebrates with marine currents in temperate regions. Sarsia 34: 209-216

Miller B, Emlet RB (1997) Influence of nearshore hydrodynamics on larval abundance and settlement of sea urchins Strongylocentrorus franciscanus and S. Purpuratus in the Oregon upwelling zone. Mar Ecol Prog Ser 148:83-94

Miron G, Bourget E, Archambault P (1996) Scale of observation and distribution of adult conspecifics: their influence in assessing passive and active settlement mechanisms in the barnacle Balanus crenatus (Bruguière). J Exp Mar Biol Ecol 201:137-158

Moreno CA, Lunecke KM, Lépez MI (1986) The response of an intertidal Concholepas concholepas (Gastropoda) population to protection from Man in southern Chile and the effects on benthic sessile assemblages. Oikos 46: 359-364

Moreno CA, Asencio G, Ibáñez S (1993) Patrones de asentamiento de Concholepas concholepas (Bruguière) (Mollusca: Muricidae) en la zona intermareal rocosa de Valdivia, Chile. Rev Chil Hist Nat 66:93-101

Moreno CA, Asencio G, Duarte WE, Martin V (1998) Settlement of the muricid Concholepas concholepas and its relationship with El Niño and coastal upwellings in southern Chile. Mar Ecol Prog Ser 167:171-175

Nathan R, Muller-Landau HC (2000) Spatial patterns of seed dispersal, their determinants and consequences for recruitment. Trends Ecol Evol 15:278-285

Navarrete SA, Wieters EA (2000) Variation in barnacle recruitment over small scales: larval predation by adults and maintenance of community pattern, J Exp Mar Biol Ecol 253:131-148

Peña G, Huepe P, Lepez I, Aracena O, Olivares O, Santos C (1994) Registro de larvas de Concholepas concholepas en el plancton costero de Bahia San Vicente y Coliumo, VIII Region. Bol Soc Biol Concepcion 65:81-87

Pineda J (1991) Predictable upwelling and the shoreward transport of planktonic larvae by internal tidal bores. Science 253:548-551

Pineda J (1999) Circulation and larval distribution in internal tidal bore warm fronts. Limnol Oceanogr 44:1400-1414

Possingham HP, Roughgarden J (1990) Spatial population dynamics of a marine organism with a complex life cycle. Ecology 71:973-985

Power ME, Tilman D, Estes J, Menge BA and 6 others (1996) Challenges in the quest for keystones. Bioscience 46: 609-620

Ramorino L (1975) Ciclo reproductivo de Concholepas concholepas en la zona de Valparaiso. Rev Biol Mar 15: 149-165

Reyes E, Romero H (1977) Climatología e interacción océano- 
atmósfera en la bahia de Valparaiso. Rev Biol Mar 16: 125-159

Rivas DA, Castilla JC (1987) Dinámica de poblaciones intermareales de Concholepas concholepas (Bruguière, 1789) (Mollusca: Gastropoda) en Chile Central. Invest Pesq 34: 3-19

Rosales S, Balbontín F (1994) Variaciones interanuales y mensuales de la temperatura superficial del mar (1961-1991) y del régimen de vientos (1966-1991) en Valparaiso y su incidencia en el reclutamiento de peces. Proc XIV Jornadas de Ciencias del Mar, Puerto Montt, Chile, p 115

Roughgarden JS, Iwasa Y, Baxter C (1985) Demographic theory for an open marine population with space-limited recruitment. Ecology 66:54-67

Roughgarden JS, Gaines S, Possingham H (1988) Recruitment dynamics in complex life cycles. Science 241:1460-1466

Roughgarden JS, Pennington JT, Stoner D, Alexander S, Miller K (1991) Collisions of upwelling fronts with the intertidal zone: the cause of recruitment pulses in barnacle population of central California. Acta Oecol 12:35-51

Sale PS (1990) Recruitment of marine species: is the bandwagon rolling in the right direction? Trends Ecol Evol 5:25-27

Scheltema RS (1971) The dispersal of the larvae of shoalwater benthic invertebrate species over long distances by ocean currents. In: Crisp DJ (ed) 4th European marine biology symposium. Cambridge Univ Press, Cambridge, p 7-28

Scheltema RS (1986) Long distance dispersal by planktonic larvae of shoal-water benthic invertebrates among Central Pacific islands. Bull Mar Sci 39:241-256

Shanks AL (1986) Vertical migration and cross-shelf dispersal of larval Cancer spp. and Randallia ornata (Crustacea: Brachyura) off the coast of southern California. Mar Biol 92:189-199

Shanks AL (1995) Mechanisms of cross-shelf dispersal of

Editorial responsibility: Kenneth Sherman (Contributing

Editor), Narragansett, Rhode Island, USA larval invertebrates and fish. In: McEdward L (ed) Ecology of marine invertebrate larvae. CRC Press, Boca Raton, FL, p 323-367

Shanks AL, Largier J, Brink L, Brubaker J, Hoff R (2000) Demonstration of the onshore transport of larval invertebrates by the shoreward movement of an upwelling front. Limnol Oceanogr 45:230-236

Sievers HA, Silva N (1979) Variación temporal de las condiciones oceanográficas frente a punta Curaumilla, Valparaiso, Chile (mayo de 1974- abril de 1975). Invest Mar Univ Catol Valparaiso 7:3-20

Stotz WB, De Amesti P, Martinez DJ, Perez E (1991) Lugares de assentamiento y desarrollo de juveniles tempranos de Concholepas concholepas (Bruguière, 1789) en ambientes inter y submareales de la IV Region, Coquimbo, Chile. Rev Biol Mar 26:339-350

Strathmann RR (1990) Why life histories evolve differently in the sea. Am Zool 30:197-207

Stuardo J (1979) Sobre la classificacion, distribucion, y variacion de Concholepas concholepas (Bruguière, 1789): un estudio de taxonomia beta. Biol Pesq 12:99-144

Strub PT, Mesias JM, Montecino V, Rutlland J, Salinas S (1998) Coastal ocean circulation off Western South America. In: Robinson AR, Brink KH (eds) The sea, Vol 11. J Wiley \& Sons, New York, p 273-313

Thorson G (1950) Reproduction and larval ecology of marine bottom invertebrates. Biol Rev 25:1-45

Tomczak M, Godfrey JS (1994) Regional oceanography: an introduction. Pergamon Press, Oxford

Wing SR, Botsford LW, Largier JL, Morgan LE (1995a) Spatial structure of relaxation events and crab settlement in the northern California upwelling system. Mar Ecol Prog Ser 128:199-211

Wing SR, Botsford LW, Quinn JF (1995b) Settlement and transport of benthic invertebrates in an intermittent upwelling region. Limnol Oceanogr 40:316-329

Submitted: September 27, 2000; Accepted: August 7, 2001

Proofs received from author(s): February 27, 2002 